\title{
The effect of a new non-toxic water-soluble selenorganic substance on antioxidant protection and development of seedlings of oilseed radish (Raphanus sativus L. var. oleiferus Metzg.)
}

\author{
Irina S. NESTERKINA ${ }^{1,2}$, Maksim V. MUSALOV ${ }^{3}$, Veronika V. GURINA ${ }^{1}$, Natalya V. OZOLINA ${ }^{1}$, Eka- \\ terina V. SPIRIDONOVA ${ }^{1}$, Anastasya V. TRETYAKOVA ${ }^{4}$, Vladimir A. POTAPOV ${ }^{3}$, Svetlana V. AMOS- \\ $\mathrm{OVA}^{3}$,Vladimir A. YAKIMOV ${ }^{3}$
}

Received May 29, 2019; accepted August 21, 2019.

Delo je prispelo 29. maja 2019, sprejeto 21. avgusta 2019.

The effect of a new non-toxic water-soluble selenorganic substance on antioxidant protection and development of seedlings of oilseed radish (Raphanus sativus L. var. oleiferus Metzg.)

Abstract: The effect of 2,6-dipyridinium selenabicyclo[3.3.1]nonandibromide ( $996 \mathrm{zh})$ on the level of lipid peroxidation (LPO), on the activity of glutathione reductase (GR) and on the morphometric parameters of oilseed radish seedlings under normal conditions and under stress $(200 \mathrm{mmol} \mathrm{NaCl})$ has been studied. It has been established that the substance 996 $\mathrm{zh}$ at a concentration of $100 \mu \mathrm{m}$ exerted an antioxidant effect reducing the level of lipid peroxidation and increasing the activity of GR. In connection with that the germinating ability of seeds and the biomass of the roots and stems of seedlings increased, both under normal conditions and under stress conditions.

The concentration of the substance $996 \mathrm{zh}$ of $1000 \mu \mathrm{mol}$ had a toxic effect, increasing the LPO level in normal conditions, but neutralized the effect of stress due to the addition of $\mathrm{NaCl}$. This concentration had a slight inhibitory effect on germinability and on root development in seedlings. However, the same concentration of the substance $996 \mathrm{zh}(1000 \mu \mathrm{mol})$ had a positive effect on the development of shoots under both normal and stressed conditions.

Key words: selenium compounds; oilseed radish; glutathione reductase; lipid peroxidation
Učinek nove nestrupene vodotopne organske spojine selena na antioksidacijsko zaščito in razvoj sejank oljne redkve (Raphanus sativus L. var. oleiferus Metzg.)

Izvleček: V raziskavi je bil preučevan učinek 2,6-dipiridinium selenabiciklo[3.3.1]nonandibromida (996 zh) na peroksidacijo lipidov (LPO), aktivnost glutation reduktaze (GR) in morfometrične parametre sejank oljne redkve v normalnih razmerah in pod slanostnim stresom (200 mmol $\mathrm{NaCl})$. Ugotovljeno je bilo, da je spojina $996 \mathrm{zh}$ pri koncentraciji $100 \mu \mathrm{mol}$ pokazala antioksidacijski učinek, kar je zmanjšalo peroksidacijo lipidov in in povečalo GR. V povezavi s sposobnostjo kalitve semen sta se biomasi korenin in stebel povečali, tako v normalnih kot v stresnih razmerah. Koncentracija 996 zh $1000 \mu$ mol je imela toksičen učinek, povečala je LPO v normalnih razmerah, a nevtralizirala učinek stresa po dodatku $\mathrm{NaCl}$. Ta koncentracija je imela rahel zavirani učinek na kalitev in razvoj korenin sejank. Kakorkoli, ista koncentracija spojine 996 zh $(1000 \mu \mathrm{mol})$ je imela pozitivni učinek na razvoj poganjkov v normalnih in stresnih razmerah.

Ključne besede: spojine selena; oljna redkev; glutation reduktaza; peroksidacija lipidov

Federal State Budgetary Institution of Science Siberian Institute of Plant Physiology and Biochemistry, Siberian Branch of the Russian Academy of Sciences, Russia

2 Corresponding author, e-mail: nirinka24@mail.ru

3 Federal State Budgetary Institution of Science A.E. Favorsky Irkutsk Institute of Chemistry, Siberian Branch of the Russian Academy of Sciences, Russia

4 Federal State Budgetary Educational Institution of Higher Education Irkutsk State University, Russia 


\section{INTRODUCTION}

Eastern Siberia covers the territory of the Central and Northern Taiga of Russia. Features of crop production in this region are dependent on harsh climatic conditions. Severe winter is a problem because freezing the soil and covering it with ice cause low oxygen conditions. Despite this, crop production in this region is developing and playing a big role in the life of the region and the country as a whole (Surinet al., 2018).

Due to the fact that the climate in this region is continental and sharply continental, the main focus of agronomy production is on spring crops such as wheat, rye, barley and oats. In addition to these main crops, cruciferous field crops are now widespread. Oilseed radish (Raphanus sativus L. var. oleiferus Metzg.) is promising for outspread due to its cold resistance, short growing season and accumulation of large yields of high-protein green mass.It is grown as a fodder, green manure, oilbearing and strip culture. To more fully use the potential of the culture, the efficiency of cultivation and the expansion of its distribution areas, it becomes necessary to develop its cultivation technology and identify the most important biological features (Dorofeevet al., 2013).

In the course of growth and development, oilseed radish, like many Siberian plants, is exposed to various stressors, the most common of which are agro-climatic conditions like drought, cold, salinisation and contamination with heavy metals. As a result of exposure to these unfavorable environmental factors in plant cells, the production of reactive oxygen species (ROS) increases, which at high concentrations have a negative impact on all vital processes in the cell (Gill \&Tuteja, 2010; Gill et al., 2013). To prevent negative effects on the cells of crops, science has developed and recommended use of a large number of complex and highly targeted substances, including ones containing selenium (Alfthanet al., 2014).

Most of the currently used selenium substances are based on inorganic selenium compounds, their complexes, selenium-containing amino acids and their derivatives due to the availability of these compounds. However, these substances have high toxicity and can have a long-term negative impact on the environment when released into soils and water bodies (Škrabanja, 2017).This fact does not allow them to be used effectively enough both as adaptogens in animal breeding and agriculture, and as preventive substances in regions characterized by lack of selenium (for example, as food additives to products of mass consumption, in the composition of multivitamin and mineral complexes).The development of available methods for the synthesis of organoselenium compounds led to a shift from the use of non-effective selenium compounds to the use of low-toxic organose- lenium substances (Nogueiraet al., 2004). Earlier, we first proposed and successfully implemented the use of selenium dihalides compounds in the synthesis of selenorganic compounds (Potapov \& Amosova, 2003). Introduction of new selenium-containing electrophilic reagents - selenium dichloride and selenium dibromide - to the organic synthesis has significantly expanded the possibilities of obtaining new organic selenium compounds (Potapovet al., 2016). Based on this approach, we obtained previously unknown 2,6-dipyridinium selenabicyclo[3.3.1] nonandibromide ( $996 \mathrm{zh}$ ). The composition and structure of the new compound are unambiguously proved by NMR methods on $1 \mathrm{H}$ and $13 \mathrm{C}$ nuclei and are confirmed by the elemental analysis data. At the next stage of work, it was necessary to check the biological activity of the obtained substance $996 \mathrm{zh}$.

Currently, it is shown that selenium plays a big role in protecting cells from ROS because it is a part of the enzymes of the glutathione antioxidant system. Thus, the purpose of our research was to study the effect of different concentrations of 2,6-dipyridinium selenabicyclo[3.3.1]nonan 2,6-dipyridyl selelenabicyclo[3.3.1] nonandibromide (996zh) on the antioxidant protection (GR, LPO) and morphometric indicators of oilseed radish sprouts both under normal and stressed conditions.

\section{MATERIALS AND METHODS}

\subsection{SYNTHESIS}

${ }^{1} \mathrm{H}(400.1 \mathrm{MHz}),{ }^{13} \mathrm{C}(100.6 \mathrm{MHz})$ NMR spectra were recorded on a Bruker DPX-400 spectrometer in $1-10 \%$ solution in $\mathrm{D}_{2} \mathrm{O}$, referenced to HMDS $\left({ }^{1} \mathrm{H}\right.$ and ${ }^{13} \mathrm{C}$ NMR, internal).

A solution of pyridine $(2 \mathrm{~g}, 25 \mathrm{mmol})$ in $5 \mathrm{ml}$ of acetonitrile was added dropwise to a solution of 2,6-dibrom-9-selenabicyclo[3.3.1] nonan (3.48 g, $10 \mathrm{mmol})$ (Accurso et al., 2011) in $25 \mathrm{ml}$ of acetonitrile. The reaction mixture was stirred for 6 hours at room temperature. The solvent was removed on a rotary evaporator, the residue was washed with $\mathrm{CCl}_{4}(3 \times 5 \mathrm{ml})$, dried in vacuum to constant mass. Product Compound 996 zh (4.97 g, $98 \%$ yield), colorless crystals, purity > $98 \% .{ }^{1} \mathrm{H}$ NMR $\left(400 \mathrm{MHz}, \mathrm{D}_{2} \mathrm{O}\right) \delta 2.34-2.41(\mathrm{~m}, 2 \mathrm{H}$, $\mathrm{SeCHCH2}$ ), $2.54-2.59$ (m, 4H, BrCHCH), $3.07-3.17$ (m, 2H, BrCHCH), $3.41-3.44$ (m, 2H, SeCH), $5.83-$ $5.89(\mathrm{~m}, 2 \mathrm{H}, \mathrm{BrCH}), 8.09\left(\mathrm{t}, 4 \mathrm{H}, m-\mathrm{H}_{\text {pyr }}\right), 8.54(\mathrm{t}, 2 \mathrm{H}$, $\left.p-\mathrm{H}_{\mathrm{pyr}}\right), 9.02\left(\mathrm{~d}, 4 \mathrm{H}, o-\mathrm{H}_{\mathrm{pyr}}\right) .13 \mathrm{C} \mathrm{NMR}\left(100 \mathrm{MHz}, \mathrm{D}_{2} \mathrm{O}\right)$ $\delta$ 25.57, 28.19, 29.37, 74.60, 128.68, 143.15, 146.46. Found: C, 42.84; H, 4.41; Br, 31.72; N, 5.54; Se, 15.49 . Calc. for $\mathrm{C}_{18} \mathrm{H}_{22} \mathrm{Br}_{2} \mathrm{~N}_{2} \mathrm{Se}: \mathrm{C}, 42.80 ; \mathrm{H}, 4.39 ; \mathrm{Br}, 31.64 ; \mathrm{N}$, 5.55; Se 15.63 . 


\subsection{PLANT MATERIAL}

Studies were carried out in laboratory conditions on oilseed radish seeds (Raphanus sativus L. var. oleiferus Metzg.) of lines of Irkutsk State Agricultural Academy, with laboratory germinability of $80-98 \%$, weighing 1,000 seeds $9.5 \mathrm{~g}$. Seeds were germinated on wet filter paper in Petri dishes at a constant temperature of $23^{\circ} \mathrm{C}$, in the dark, for 4 days, wetting them with the test solutions. The number of seeds in one cup was 30 pcs. The experiment was repeated 3 times.

\subsection{EVALUATION OF GERMINABILITY AND MASS OF SEEDLINGS}

Germinability was analyzed according to the AllUnion State Standard 10-14-86 "Oilseed Radish Seeds. Varietal and sowing qualities". These indicators were determined in accordance with All-Union State Standard 12038-84 "Seeds of agricultural crops. Methods for determining germinability" (Dorofeev et al., 2013). The mass of shoots and roots was determined using the gravimetric analysis.

\subsection{DETERMINATION OF PROTEIN CONTENT}

Protein contentwas determined by the degree of binding to the Coomassie blue dye (CBB G250 "Sigma") according to the Bradford method (Bradford, 1976).

\subsection{DETERMINATIONS OF GLUTATHIONE RE- DUCTASE ACTIVITY}

Glutathione reductase activity (EC 1.6.4.2) was measured according to the method described by Nigmatullina et al. (2014). The activity of glutathione reductase was determined by the change in absorption at $340 \mathrm{~nm}$, caused by the oxidation of NADPH in 3.5 min with an interval of $1 \mathrm{~s}$ on the spectrophotometer. The enzyme activity was calculated using the extinction coefficient for $\mathrm{NADP}+$ at a wavelength of $340 \mathrm{~nm}$, equal to $6.22 \mathrm{mmol}^{-1}$ $\mathrm{cm}^{-1}$.

\subsection{EVALUTION OF DIENE CONJUGATES}

Analysis of the content of the primary products of lipid peroxidation - diene conjugates (DC) -was carried out according to the method (Placer, 1968) in our modification. The measurement was performed on a spectro- photometer at a wavelength of $203 \mathrm{~nm}$. The obtained optical density (D) was used to calculate the concentration of diene conjugates (recalculated per $1 \mathrm{~g}$ wet mass) using an extinction coefficient equal to $2.2 \times 10^{5} \mathrm{~mol}^{-1} \mathrm{~cm}^{-1}$.

Salinisation was chosen as a stress, which was created with $\mathrm{NaCl}$, a concentration of $200 \mathrm{mmol}$ was taken from literature data (Ahmad et al., 2015). This concentration causes stress, since it significantly increases the level of lipid peroxidation by almost two times compared with the control (Table 1).

\section{$2.7 \quad$ STATISTICS}

The data are presented as arithmetic mean values of quantities and their standard deviations, which were obtained in three independent experiments, calculated using Microsoft Excel. The statistical significance of the differences of the compared average values was evaluated using the Mann-Whitney U-test.

\section{RESULTS AND DISCUSSION}

The effect of the new selenium-containing substance $996 \mathrm{zh}$ on the morphometric and biochemical parameters of oil radish under normal conditions and in salt conditions was studied. The objective of the work was to identify which concentrations of the substance exhibit antioxidant activity. This was done using various concentrations $(1000,500,200,100,50,10 \mu \mathrm{mol})$. Antioxidants are mainly used for organisms under stress (Alfthan et al., 2014). Therefore, the work of substance $996 \mathrm{zh}$ was tested both under normal and stressful conditions, which allowed us to more fully trace the antioxidant effect of substance $996 \mathrm{zh}$. Based on the results of the work, $1000 \mu \mathrm{mol}$ and $100 \mu \mathrm{mol}$ concentrations were chosen. A concentration of $100 \mu \mathrm{mol}$ showed a good antioxidant effect under both normal and stressful conditions. A concentration of $1000 \mu \mathrm{mol}$ showed an antioxidant effect under stress. Selenium is known to play a large role in antioxidant plant protection (Mugesh et al., 2001).In connection with this, at the first stage of our work, we determined the content of diene conjugates and the activity of glutathione reductase. According to the data obtained, it can be seen that the substance $996 \mathrm{zh}$ at a concentration of $100 \mu \mathrm{mol}$ reduces the level of lipid peroxidation, under both normal and stressed conditions (Table 1). The concentration of the substance $996 \mathrm{zh} 1000 \mu \mathrm{mol}$ under normal conditions had a toxic effect; it increased the level of LPO by two times compared with the control. A similar manifestation regarding the effect of selenium was observed on broccoli plants with low sulfur content 
Table 1: The effect of substance $996 \mathrm{zh}$ on the content of diene conjugates (LPO) and the activity of glutathione reductase under normal conditions and under stress conditions

\begin{tabular}{llcc}
\hline № & Variant & $\begin{array}{l}\text { Diene conjugates, } \\
\text { nmol on 1 gram wet mass }\end{array}$ & $\begin{array}{l}\text { Glutathione reductase activity, } \\
\mathrm{mmol} \mathrm{min}^{-1} \mathrm{mg}^{-1}\end{array}$ \\
\hline 1 & $\mathrm{H}_{2} \mathrm{O}($ control) & $0.72 \pm 0.07$ & $7.81 \pm 2.4$ \\
2 & $1000 \mu \mathrm{mol} 996 \mathrm{zh}$ & $1.14 \pm 0.03^{\star}$ & $8.39 \pm 1.4$ \\
3 & $100 \mu \mathrm{mol} 996 \mathrm{zh}$ & $0.50 \pm 0.02^{\star}$ & $38.53 \pm 3.51^{\star}$ \\
4 & $200 \mathrm{mmol} \mathrm{NaCl}$ (control for stress) & $1.30 \pm 0.02^{*}$ & $4.8 \pm 0.05$ \\
5 & $200 \mathrm{mmol} \mathrm{NaCl}+1000 \mu \mathrm{m} 996 \mathrm{zh}$ & $0.83 \pm 0.05^{\star *}$ & $4.19 \pm 0.62$ \\
6 & $200 \mathrm{mmol} \mathrm{NaCl}+100 \mu \mathrm{m} 996 \mathrm{zh}$ & $0.68 \pm 0.03^{* *}$ & $7.36 \pm 5.39$ \\
\hline
\end{tabular}

${ }^{*}$ Differences from control $p \leq 0.01 ;{ }^{* *}$ Difference from control for stress $p \leq 0.0$. Value represents mean \pm standard error of three replicates.

in the nutrition environment (Tianet al., 2017). The same concentration $(1000 \mu \mathrm{mol})$ neutralized the effect of stress almost to the control level (Table 1). A similar positive effect of selenium on oxidative stress created by heavy metals, salinisation, cooling on various crops (cucumber, sunflower) was shown by Saidi (Saidi et al., 2014) and Hawrylak-Nowak (Hawrylak-Nowak et al., 2010).

The key parameters for the antioxidant protective potential are the redox status of glutathione, which under normal conditions is significantly shifted towards the reduced form. Support of the redox status of glutathione is provided by a number of enzymes, the main of which is glutathione reductase (GR) (Gill et al., 2013). Glutathione reductase catalyzes the conversion of oxidized glutathione (GSSG) to reduced glutathione (GRH) and is an important component of the ROS detoxification system in plants (Gill et al., 2013). Selenium is known to affect the activity of enzymes of the glutathione plant protection system (Mugeshet al., 2001).In this regard, in our work, we investigated the effect of $996 \mathrm{zh}$ on the activity of glutathione reductase (GR) in plants grown under normal conditions and under stress $(200 \mathrm{mmol} \mathrm{NaCl})$.

According to Table 1, it can be seen that in some variants $(3 ; 4 ; 6)$ there is a relationship between the content of diene conjugates and the activity of glutathione reductase, namely, with an increase in the activity of GR, the level of LPO decreases and, conversely, with a decrease in the activity of GR, the level of LPO increases (Table 1). Earlier it was shown that salt stress $(150 \mathrm{mmol}$ $\mathrm{NaCl}$ ) leads to a strong increase in the GR activity in salt-tolerant plants (Ahmad et al., 2015).Oil radish does not belong to salt tolerant plants, therefore, we presume that the activity of GR during salinity of chlorides did not increase, but decreased.It is interesting, that the concentration of the substance $996 \mathrm{zh} 100 \mu \mathrm{mol}$ restored the activity of GR to the level of control even under stress condition. Under normal conditions, the effect of this concentration increased the activity of GR by several times as compared with the control; that was reflected in a decrease in the level of LPO. The concentration of $1000 \mu \mathrm{mol}$ of substance $996 \mathrm{zh}$ under normal and stressful conditions did not show significant differences.

Evaluation of the level of LPO and the activity of GR showed that the substance 996 zh exhibits an antioxidant effect under both normal and stressed conditions. Morphometric parameters of the organism as a whole are known to depend on the biochemical processes occurring in the cells. Seed germinability is an important indicator for crops, as it affects density of sowing and evenness of plant stand. Germinability is determined by soil and climatic conditions, growing technology and fertilizer systems. It is known that the germinability of oilseed radish in Eastern Siberia can vary from 40-90\% depending on agro-climatic conditions (Dorofeevet al., 2013).That is why increasing oilseed radish seeds germinability is a pressing issue in regions with a sharply continental climate (Kashevarovet al., 2016). Therefore, we determined the effect of the substance $996 \mathrm{zh}$ on the germinability of the given culture under both normal and stressed conditions. Concentrations of the substance $996 \mathrm{zh}$, used in the work, showed the same results both under normal conditions and under salinisation conditions (Fig. 1). The concentration of $1000 \mu \mathrm{m}$ inhibits germinability and the concentration of $100 \mu \mathrm{mol}$ activates it. The data obtained may reflect the effect of $996 \mathrm{zh}$ on the activity of GR and the level of LPO. Under normal conditions, the concentration of the substance 996 zh 1000 $\mu \mathrm{mol}$ increased the level of LPO and had almost no effect on the activity of GR; that caused the inhibition of germinability. A similar effect was observed at salinisation; the concentration of the substance $996 \mathrm{zh} 1000 \mu \mathrm{mol}$ increased the level of LPO in comparison with the control, but reduced it compared to the control for stress. The concentration of the substance $996 \mathrm{zh} 1000 \mu \mathrm{mol}$ did not affect the activity of GR (Table 1). As a result, germinability decreased (Fig. 1). It is noted that selenium concentration from 150-300 $\mu \mathrm{mol}$ has a negative effect on germinability and germinative energy for such crops 


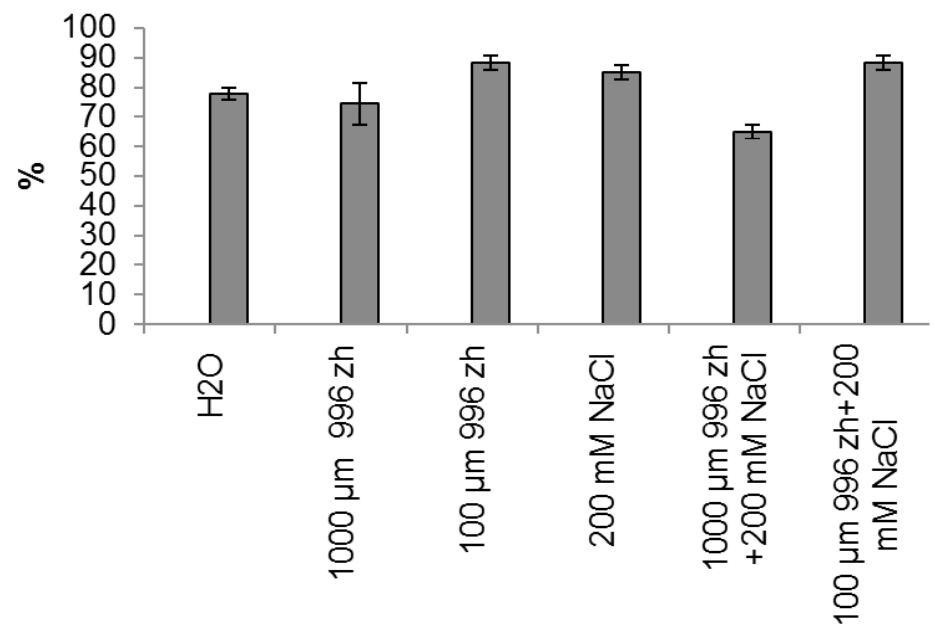

Figure 1: The effect of $996 \mathrm{zh}$ on the oilseed radish seeds germinability under normal conditions and under stress conditions. Value represents mean \pm standard error of three replicates.

as wheat, oats, and rye. For barley, these concentrations were destructive (Sindirevaet al., 2013).

The opposite phenomenon was observed when exposed to a concentration of the substance $996 \mathrm{zh}$ $100 \mu \mathrm{mol}$ (Fig. 1). The level of LPO in seedlings decreased both under normal and stressed conditions, while the GR activity increased (Table 1).It is known that GR reduces the oxidized form of glutathione to the reduced form. In this regard, an increase in GR activity indicates that more reduced glutathione is formed in the cells, which is involved in protecting cells from oxidative damage (Sao et al., 2017). Therefore, the germinability of seeds increased (Fig. 1). It has been shown that when exposed to low concentrations with preparations containing selenium $(50 \mu \mathrm{mol})$ on seeds of cultivated plants, seed germinability also increases (Nikonov et al., 2009). For pulses (beans, chickpea, soybean), selenium concentration from 10-60 $\mu \mathrm{mol}$ had a positive effect on germinability and germinative energy (Kokorina et al., 2015; Chernenko et al., 2017).

In addition to germinability, there are a number of indicators that are not rated by standards, but are of great importance for assessing the quality of seeds. The biomass of the roots and stems of seedlings is an important indicator, as it reflects the further development of plants (Hajibolandet al., 2015; Sao et al., 2017).
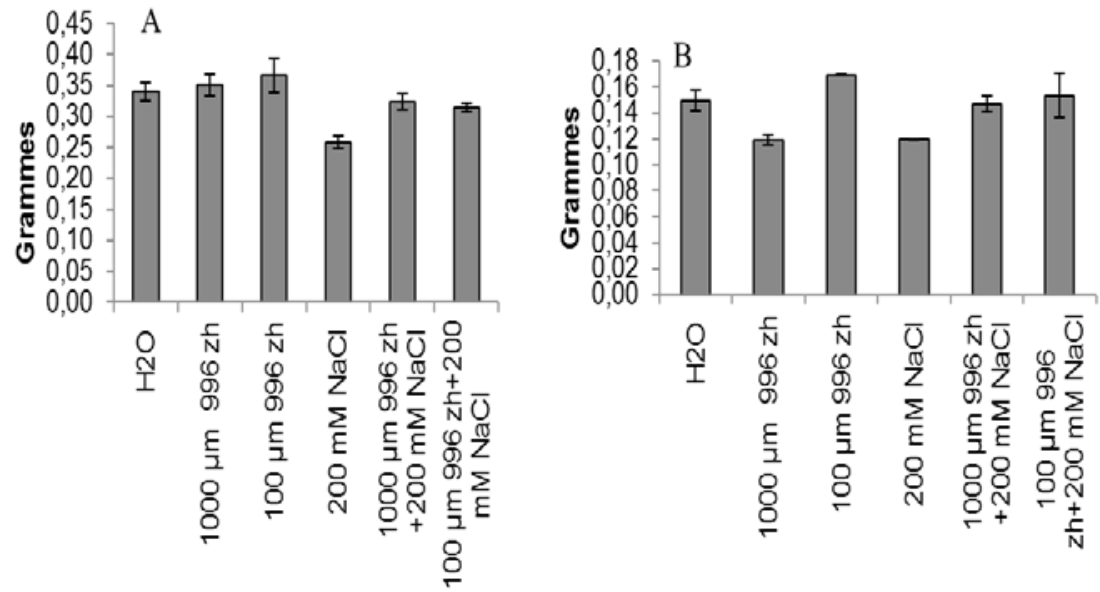

Figure 2: The effect of $996 \mathrm{zh}$ on the mass of the roots (A) and shoots (B) of seedlings of oilseed radish under normal conditions and under stress conditions. Value represents mean \pm standard error of three replicates. 
The effect of substance $996 \mathrm{zh}$ on seedling biomass showed that both for roots and for stems under stress, both concentrations $1000-100 \mu \mathrm{mol}$ have a positive effect increasing the mass of roots and stems compared to the control for stress (Fig. 2). The concentration of $1000 \mu \mathrm{mol}$, under normal conditions, inhibited the development of the roots of seedlings that affected their mass. However, the same concentration of the substance $996 \mathrm{zh}$ had a positive effect on the development of the stems and, accordingly, on their mass (Fig. 2). This suggests that as the seedlings develop, the growth of the root system slows down when the concentration of the substance $996 \mathrm{zh}$ is $1000 \mu \mathrm{mol}$. The concentration of the substance $100 \mu \mathrm{mol}$ had a positive effect on the biomass of the seedlings; especially, the effect was on the mass of the roots (Fig. 2).

An increase in the biomass of the aboveground and underground parts of wheat is observed when processing with selenium nanoparticles (Yurkova \& Omelchenko, 2015). The effect of selenium in concentrations of $10^{-6}$ and $10^{-7}$ also had a stimulating effect on the roots and stems of soybean seedlings; the concentration of $10^{-4}$ was excessive and had an inhibitory effect (Kokorinaet al., 2015)

Thus, the studied new non-toxic water-soluble seleniumorganic substance $996 \mathrm{zh}$ at a concentration of 1000-100 $\mu \mathrm{mol}$ stimulates the antioxidant protection of seedlings, while improving their morphometric parameters, both under normal and stressed conditions. Therefore, on the basis of this substance, it is possible to create preparations for the treatment of seeds of agricultural crops.

\section{ACKNOWLEDGMENT}

The authors express their deep gratitude to the research member of the laboratory of physiological and biochemical adaptation of SIPPB SB RAS, Ph.D. Katysheva Natalia Bairovna for providing oilseed radish seeds (Raphanus sativus L. var. oleiferus Metzg.) of the line of Irkutsk State Agricultural Academy. The authors are grateful to the Baikal Analytical Center SB RAS for providing the instrumental equipment.

The work of Irkutsk institute of chemistry SB RAS (synthesis and purification 996zh) was performed with financial support from the Russian Foundation of Basic Research (grant No. 18-03-00859 A).

\section{REFERENCES}

Accurso, A. A., Cho, S. H., Amin,A., Potapov, V. A., Amosova,
S. V., Finn, M. G.(2011). Thia-, Aza-, and Selena[3.3.1]bicyclononane Dichlorides: Rates vs Internal Nucleophile in Anchimeric Assistance. The Journal of Organic Chemistry, 76, 4392-4395. https://doi/10.1021/jo102440k

Alfthan, G., Eurola, M., Ekholm, P.,Venäläinen, E. R., Root, T., Korkalainen, K., Hartikainen, H., Salminen, P., Hietaniemi, V., Aspila, P., Aro, A. (2015). Effects of nationwide addition of selenium to fertilizers on foods, and animal and human health in Finland: From deficiency to optimal selenium status of the population. Journal Of Trace Elements In Medicine And Biology, 31, 142-7. https://doi/10.1016/j. jtemb.2014.04.009

Ahmad, P., Hashem, A., Abd-Allah, E. F., Alqarawi, A. A., John, R., Egamberdieva, D., Gucel, S. (2015). Role of Trichoderma harzianum in mitigating $\mathrm{NaCl}$ stress in Indian mustard (Brassica juncea L) through antioxidative defense system. Frontiers in Plant Science, 6, 868. https://doi/10.3389/ fpls.2015.00868

Bradford, M. (1976). A rapid and sensitive method for the quantitation of microgram quantities of protein utilizing the principle of protein-dye binding. Analytical Biochemistry, 72, 248-254. https://doi.org/10.1016/0003-2697(76)905273

Chernenko, K. I., Balakova, A. A., Shmarina, Y. G., Ryaskova, K.E. (2017). Prospects for the use of leguminous crops in the creation of selenium-enriched crop production. Unique research of the XXI century, 1, 26-29.

Dorofeev, N. V., Bojarkin, E. V., Peshkova, A. A. (2013). Factors defining field germination of oilseed radish seeds. Journal of Stress Physiology \& Biochemistry, 9, 159-168.

Gill, S. S., Tuteja, N. (2010). Reactive oxygen species and antioxidant machinery in abiotic stress tolerance in crop plants. Plant Physiology and Biochemistry, 48, 909-30. https:// doi/10.1016/j.plaphy 2010.08.016

Gill, S. S., Anjum, N. A., Hasanuzzaman, M., Gill, R., Trivedi, D. K., Ahmad, I., Pereira, E., Tuteja, N. (2013). Glutathione and glutathione reductase: a boon in disguise for plant abiotic stress defense operations. Plant Physiology and Biochemistry, 70, 204-12. https://doi:10.1016/j.plaphy.2013.05.032

Kashevarov, N. I., Mustafin, A. M., Kharchevnikov, V. V. (2016). Radish oil in Siberia. Novosibirsk: publishing house of the RAS. FASE Russia. FSBSI Siberian scientific research Institute of feed. 129 p.p.

Kokorin, A. L., Petrova, N. A., Dem-Roy, G. B. (2015). Effect of trace elements of sprouted seeds of soybean varieties of the Northern ecotype. News of Saint-Petersburg state agrarian University, 40, 28-33.

Mugesh, G., Panda, A., Singh, H. B., Punekar, N. S., Butcher, R.J. (2001). Glutathione Peroxidase-like Antioxidant Activity of Diaryl Diselenides: A Mechanistic Study. Journal Of The American Chemical Society, 123, 839-850. https:// doi/10.1021/ja994467p

Nikonov, I. N., Ivanov, L. I., Kovalenko, L. V., Folmanis, G. E.(2009). The influence of nanoscale selenium on the growth of agricultural crops. Promising material, 4, 54-57.

Nigmatullina, L. R., Rumyantseva, N. I., Kostyukova, Y. A. (2014). The effect of D,L -buthionine - S,R -sulfoximine on the ratio of glutathione forms and the growth of Tatar buck- 
wheat calli. Ontogenesis, 45, 50-62. https://doi.org/10.1134/ S1062360414010056

Nogueira, C. W., Zeni, G., Rocha, J. B. T. (2004). Organoselenium and organotellurium compounds. Toxicology and pharmacology. Chemistry Revie, 104, 6255-6286. https:// doi.org/10.1021/cr0406559

Hajiboland, R., Sadeghzadeh, N., Ebrahimi, N., Sadeghzadeh, B., Mohammadi, S. A. (2015). Influence of selenium in drought-stressed wheat plants under green house and field conditions. Acta agriculturae Slovenica, 105, 175 - 191. https://doi:10.14720/aas.2015.105.2.01

Hawrylak-Nowak, B., Matraszek, R., Szymańska, M. (2010). Selenium modifies the effect of short-term chilling stress on cucumber plants. Biological Trace Element Research, 138, 307-15. https://doi.org/10.1007/s12011-010-8613-5

Placer, Z. (1968). Lip peroxidation systeme im biologischen material. Nahrung, 12, 679. https://doi.org/10.1002/ food.19680120615

Potapov, V. A.,Amosova, S.V. (2003). New methods for preparation of organoselenium and organotellurium compounds from elemental chalcogens. Russian Journal of Organic Chemistry, 39, 1373-1380. https://doi.org/10.1023/ B:RUJO.0000010549.08131.18

Potapov, V. A., Musalov M. V., Musalova M. V., Amosova S. V. (2016). Recent Advances in Organochalcogen Synthesis Based on Reactions of Chalcogen Halides with Alkynes and Alkenes. Current Organic Chemistry, 20, 136145. https:// doi.org/10.1002/chin.201618224

Saidi, I., Chtourou, Y., Djebali, W. (2014). Selenium alleviates cadmium toxicity by preventing oxidative stress in sunflow- er (Helianthus annuus) seedlings. Journal of Plant Physiology, 171, 85-91. https://doi/10.1016/j.jplph.2013.09.024

Sao, A., Saraf, P., Bagchi, D. (2017). Effect of salinity on Brassica rapa var. toria (BRSRT) under selenium defence: A trial to assess the protective role of selenium. Acta agriculturae Slovenica, 109, 577 - 592. https://doi:10.14720/ aas.2017.109.3.09

Sindirepa, A. V., Stepanova, O. V., Serebrennikova, A. A. ( 2013) Influence of selenium and iodine on growth and development of grain crops. Materials XI all-Russian scientific and practical conference of students, postgraduates and young scientists, which was held in Perm, Russia. Publishing house of Perm national research Polytechnic University, 233-241.

Škrabanja, V. (2017). An effective way of adding selenium to everyday food with a focus on plant resources. Acta agriculturae Slovenica, 109, 147 - 155. https://doi:10.14720/ aas.2017.109.1.14

Surin, N. A., Lyakhov, N. E., Gerasimov, S. A., Lepshin, A. G. (2018). Evaluation of collection samples of spring barley in breeding for productivity and quality of grain in Eastern Siberia. The Achievements of Science and Technology, Agriculture, 32, 41-44.

Tian, M., Hui, M., Thannhauser, T. W., Pan, S., Li, L. (2017). Selenium-Induced Toxicity Is Counteracted by Sulfur in Broccoli (Brassica oleracea L. var. italica). Frontiers in Plant Science, 8, 1425. https://doi.org/10.3389/fpls.2017.01425

Yurkova, I. N., Omelchenko, V. V. (2015). Influence of nanoparticles of selenium and sodium Selenite on the growth and development of wheat plants. Scientific notes of V. I. Vernadsky Crimean Federal University Series Biology, Chemistry, 1,99-106. 